\title{
FORMULASI SABUN MANDI PADAT DARI EKSTRAK LIMBAH KULIT BUAH NAGA MERAH (Hylocereus Costaricensis)
}

\author{
Qurrata Ayun, Reny Eka \\ Program Studi Kimia, Fakultas Matematika dan Ilmu Pengetahuan Alam \\ Universitas PGRI Banyuwangi \\ Email: qurataayun@unibabwi.ac.id
}

\begin{abstract}
ABSTRAK
Kulit yang bersih, sehat merupakan dambaan hampir semua wanita. Semakin bertambahnya usia kulit cenderung semakin tidak sehat dan kusam. Antioksidan merupakan "pemangsa" radikal bebas sekaligus pelindung kulit. Antioksidan dapat memperbaiki kerusakan sel kulit yang terjadi sebagai akibat dari paparan sinar UV. Salah satu sumber antioksidan di alam adalah buah naga. Kandungan kimia dari kulit buah naga merah antara lain adalah flavonoid, vitamin A, C, E dan polifenol (Siregar, 2011). Pada penelitian ini, peneliti ingin memanfaatkan limbah kulit buah naga merah untuk diolah menjadi sabun mandi padat. Sabun mandi padat yang dibuat dengan memanfaatkan ekstrak limbah kulit buah naga merah sebagai zat aditif atau zat tambahan. Sebagai antioksidan vitamin $\mathrm{C}$ juga dapat langsung menangkap radikal bebas baik dengan atau tanpa katalisator enzim. Selain mengandung vitamin $\mathrm{C}$, kulit buah naga merah juga mengandung antosianin yang dipercaya berperan dalam sistem biologis, termasuk kemampuan sebagai pengikat radikal bebas, antikarsinognik, antinoplastik dan juga berfungsi sebagai anti-inflamasi. Sistem ikatan rangkap terkonjugasi ini juga mampu menjadikan antosianin sebagai antioksidan dengan mekanisme penangkapan radikal. Inilah yang menjadi dasar ekstrak kulit buah naga merah dijadikan sebagai zat tambahan pada pembuatan sabun padat. Berdasarkan hasil penelitian pelarut aquadest memberikan kadar vit C (antioksidan) yang besar dengan kondisi maserasi suhu $40^{\circ} \mathrm{C}(2$ jam). Dari seluruh perlakuan atau formulasi sabun yang dilakukan penambahan ekstrak terbaik adalah $50 \mu \mathrm{L}, 6 \mathrm{~g}$ minyak kelapa, $12,5 \mathrm{~mL} \mathrm{NaOH} \mathrm{15 \% ,} 3 \mathrm{~g}$ asam stearat, $10 \mathrm{~mL}$ etanol 96\%, 6,5 g gliserin, 7,5 g gula pasir, $500 \mu \mathrm{L}$ coco-DEA, $0,1 \mathrm{~g} \mathrm{NaCl}$ dan fragrance oil $45 \mu \mathrm{L}$
\end{abstract}

Kata kunci: sabun mandi padat, kulit buah naga merah, antioksidan

\begin{abstract}
Clean, healthy skin is the dream of almost all women. The more age the skin tends to be more unhealthy and dull. Antioxidants are "predators" of free radicals and protective skin. Antioxidants can repair damage to skin cells that occur as a result of exposure to UV light. One source of antioxidants in nature is dragon fruit. The chemical content of red dragon fruit skin includes flavonoids, vitamins A, C, E and polyphenols (Siregar, 2011). In this study, researchers wanted to use red dragon fruit peel waste to be processed into solid bath soap. Solid bath soap made by utilizing red dragon fruit peel extract as additives or additives. As an antioxidant, vitamin $\mathrm{C}$ can also directly capture free radicals with or without an enzyme catalyst. Besides containing vitamin $\mathrm{C}$, red dragon fruit skin also contains anthocyanins which are believed to play a role in biological systems, including the ability to bind free radicals, anticancer drugs, antinoplastic and also function as anti-inflammatory. This conjugated double bond system is also capable of making anthocyanins as antioxidants with a
\end{abstract}


radical capture mechanism. This is the basis of the extract of red dragon fruit skin as an additive to the manufacture of solid soap. Based on the results of the aquadest solvent research, it gives a large amount of vit $\mathrm{C}$ (antioxidant) with maceration conditions of $40{ }^{\circ} \mathrm{C}$ ( 2 hours). Of all the soap treatments or formulations which were carried out the best extracts were $50 \mu \mathrm{L}, 6 \mathrm{~g}$ coconut oil, $12.5 \mathrm{~mL} 15 \% \mathrm{NaOH}, 3 \mathrm{~g}$ stearic acid, $10 \mathrm{~mL} 96 \%$ ethanol, $6.5 \mathrm{~g}$ glycerin, $7.5 \mathrm{~g}$ sugar sand, $500 \mu \mathrm{L}$ coco-DEA, $0.1 \mathrm{~g} \mathrm{NaCl}$ and fragrance oil $45 \mu \mathrm{L}$

Keywords: solid soap, red dragon fruit peels, antioxidants

\section{PENDAHULUAN}

Memiliki kulit yang bersih, sehat merupakan dambaan hampir semua wanita. Berbagai macam cara dilakukan untuk mendapatkan kulit yang sehat mulai dari cara tradisional sampai dengan cara modern seperti penggunaan kosmetik yang berbahan dasar bahan-bahan kimia, suntik botoks, atau operasi plastik. Beberapa wanita lebih memilih cara modern untuk mendapatkan kulit idaman mereka, karena lebih praktis dan instant, namun ada sisi buruk dari penggunaan cara-cara modern tersebut bagi kesehatan.

Sekarang ini keadaan kulit yang tidak sehat dan cenderung kusam tidak hanya disebabkan oleh bertambahnya usia saja, ada beberapa faktor lain yang menyebabkan hal tersebut terjadi seperti tingginya stress, tingginya polusi udara, perokok, terpapar radikal bebas, terpapar sinar matahari dan sinar UV sehingga dapat menurunkan produksi kolagen dan akumulasi elastin abnormal. Pemangsa radikal bebas sekaligus pelindung kulit adalah antioksidan.

Salah satu sumber antioksidan di alam adalah buah naga. Buah naga dapat tumbuh di iklim tropis Indonesia, sehingga buah satu ini mudah dijumpai dipasaran. Buah naga mulai banyak dikonsumsi karena kandungan kimianya yang bermanfaat bagi kesehatan. Umumnya orang hanya mengkonsumsi daging buahnya saja dan kulitnya dijadikan limbah. Namun, tanpa kita sadari dengan menjadikan kulit buah naga menjadi limbah sama saja membuang berbagai manfaat yang tersimpan didalamnya. Kulit buah naga mengandung vitamin $\mathrm{C}$, vitamin $\mathrm{E}$, vitamin $\mathrm{A}$, alkaloid, terpenoid, flavonoid, tiamin, niasin, piridoksin, kobalamin, fenolik, karoten, dan fitoalbumin (Jaafar,et al.,2009). 
Pada penelitian ini, peneliti ingin memanfaatkan limbah kulit buah naga merah untuk diolah menjadi sabun mandi padat. Sabun mandi merupakan salah satu sarana untuk membersihkan diri dari kuman, kotoran, bakteri dan hal-hal lain yang membuat tubuh menjadi kotor, kusam dan tidak sehat. Sabun sendiri merupakan surfaktan yang digunakan dengan air untuk mencuci dan membersihkan. Sabun yang dikenal saat ini ada bermacam-macam antara lain adalah sabun padat biasa (opqaue), sabun cair (liquid soap) dan juga ada sabun padat transparan. Sabun mandi padat yang dibuat dengan memanfaatkan ekstrak limbah kulit buah naga merah sebagai zat aditif atau zat tambahan. Kulit buah naga ini mengadung vitamin C. Sebagai antioksidan vitamin $\mathrm{C}$ juga dapat langsung menangkap radikal bebas baik dengan atau tanpa katalisator enzim. Selain mengandung vitamin $\mathrm{C}$, kulit buah naga merah juga mengandung antosianin yang dipercaya berperan dalam sistem biologis, termasuk kemampuan sebagai pengikat radikal bebas (free radical scavnging), antikarsinognik, antinoplastik dan juga berfungsi sebagai anti-inflamasi. Warna yang diberikan oleh antosianin disebabkan adanya susunan ikatan rangkap terkonjugasinya yang panjang, sehingga mampu menyerap cahaya pada rentang cahaya tampak. Sistem ikatan rangkap terkonjugasi ini juga mampu menjadikan antosianin sebagai antioksidan dengan mekanisme penangkapan radikal (antosianin merupakan senyawa flavonoid yang memiliki kemampuan sebagai antioksidan). Inilah yang menjadi dasar ekstrak kulit buah naga merah dijadikan sebagai zat tambahan pada pembuatan sabun padat.

\section{METODE PENELITIAN}

\subsection{Preparasi Sampel}

Buah naga merah dikupas kemudian dibersihkan untuk memisahkan daging buah dengan kulitnya. Selanjutya kulit buah naga di haluskan menggunakan cawan porselen.

\subsection{Formulasi Pembuatan Sabun Mandi Padat Ekstrak Kulit Buah Naga Merah}

\subsubsection{Optimasi Volume Ekstrak Kulit Buah Naga Merah}


Pembuatan sabun padat dari ekstrak kulit buah naga merah, dilakukan dengan mencampurkan $10 \mathrm{~g}$ minyak kelapa, $10 \mathrm{~mL}$ larutan $\mathrm{NaOH} \mathrm{30 \% ,} \mathrm{3,5} \mathrm{g} \mathrm{asam}$ stearat, $10 \mathrm{~mL}$ etanol 96\%, 6,5 g gliserin, 7,5 g gula pasir yang telah dilarutkan dengan aquadest, $500 \mu \mathrm{L}$ coco-DEA, $0,1 \mathrm{~g} \mathrm{NaCl}, 30 \mu \mathrm{L}$ fragrance oil serta ekstrak kulit buah naga merah yang volumenya divariasikan 0, 50, 100, 150 dan $200 \mu \mathrm{L}$. Selanjutnya dilakukan uji kualitas sabun untuk mendapatkan formulasi yang paling bagus untuk selanjutnya dipakai pada optimasi selanjutnya.

\subsubsection{Optimasi Konsentrasi $\mathrm{NaOH}$}

Pembuatan sabun padat dari ekstrak kulit buah naga merah, dilakukan dengan mencampurkan semua bahan dengan $10 \mathrm{~mL}$ larutan $\mathrm{NaOH}$ dengan konsentrasi yang divariasikan yaitu 5\%, 10\%, 15\%, 20\%, 25\% dan 30\%.

\subsubsection{Optimasi Massa Minyak}

Pembuatan sabun padat dari ekstrak kulit buah naga merah, dilakukan dengan mencampurkan semua bahan dengan minyak kelapa yang divariasikan massanya yaitu, $6 \mathrm{~g}, 7 \mathrm{~g}, 8 \mathrm{~g}, 9 \mathrm{~g}$ dan $10 \mathrm{~g}$.

\subsubsection{Optimasi Massa Asam Stearat}

Pembuatan sabun padat dari ekstrak kulit buah naga merah, dilakukan dengan mencampurkan semua bahan dengan asam stearat dengan variasi massa $3 \mathrm{~g}$, $3,5 \mathrm{~g}, 4 \mathrm{~g}, 4,5 \mathrm{~g}$ dan $5 \mathrm{~g}$.

\subsubsection{Optimasi Massa Gula Pasir}

Pembuatan sabun padat dari ekstrak kulit buah naga merah, dilakukan dengan mencampurkan semua bahan dengan gula pasir yang telah dilarutkan dengan aquadest dg variasi massa $6,5 \mathrm{~g}, 7,5 \mathrm{~g}, 8,5 \mathrm{~g} 9,5 \mathrm{~g}$ dan 10,5 $\mathrm{g}$.

\subsection{Uji Kualitas Sabun}

\subsubsection{Preparasi Sampel}

Sabun yang akan diuji dipotong-potong halus secepat mungkin dan segera dimasukkan kedalam botol bertutup asah dan campur sampai homogen dan harus segera digunakan. 


\subsubsection{Uji Alkali Bebas}

$100 \mathrm{~mL}$ alkohol yang telah dididihkan ditambahkan dengan 0,5 mL phenopthalen dan dinginkan sampai suhu $70^{\circ} \mathrm{C}$ kemudian dinetralkan dengan $\mathrm{KOH}$ $1 M$ dalam alkohol. Kemudian sebanyak $5 \mathrm{~g}$ sampel sabun dimasukkan dalam campuran larutan tersebut dan panaskan sampai larut. selanjutnya larutan dititrasi menggunakan $\mathrm{HCl}$ 0,1 N dalam alkohol sampai warna merah tepat hilang. Selanjutnya kadar alkali bebas dihhitung berdasarkan persamaan dibawah ini:

$$
\text { kadar alkali bebas dihitung } \mathrm{NaOH}=\frac{\mathrm{V}_{\mathrm{HCl}} \times \mathrm{N} \times 0,04}{\text { massa sampel }} \times 100 \%
$$

\subsubsection{Uji Kadar Air}

Sebanyak $4 \mathrm{~g}$ sabun yang akan diuji dipanaskan dalam oven suhu $105^{\circ} \mathrm{C}$ selama 2 jam sampai massanya konstan. Selanjunya besarnya kadar air dihitung bedasarkan persamaan :

$$
\text { Kadar air }=\frac{\mathrm{W}_{1}-\mathrm{W}_{2}}{\mathrm{~W}} \times 100 \%
$$

Dimana $: W_{l}=$ massa sampel + cawan

$$
\begin{aligned}
& W_{2}=\text { massa sampel setelah dioven } \\
& W=\text { massa sampel }
\end{aligned}
$$

\subsubsection{Uji pH Sabun}

Derajat keasaman $(\mathrm{pH})$ sabun berkisar antara $9-10,8$.

\section{HASIL DAN PEMBAHASAN}

Pembuatan sabun mandi padat dengan penambahan ekstrak kulit buah naga merah pada campurannya ini bertujuan untuk memanfaatkan limbah kulit buah naga merah yang mempunyai kandungan antioksidan yang sangat bagus untuk kulit. Pengamatan yang dilakukan pada penelitian ini meliputi penentuan kadar vitamin $\mathrm{C}$ pada kulit buah naga bertujuan untuk mengetahui seberapa besar kandungan antioksidan yang terdapat dalam kulit buah naga merah. Karena salah satu gizi yang berperan sebagai antioksidan dan efektif mengatasi radikal bebas yang dapat merusak sel/jaringan, termasuk melindungi kulit dari kerusakan oksidatif yang ditimbulkan oleh radiasi adalah vitamin $\mathrm{C}$ dengan cara melakukan pemilihan pelarut, konsi maserasi yang cocok untuk mengekstrak vitamin $\mathrm{C}$ dari kulit buah naga merah. Jika 
telah diperoleh kondisi optimum, selanjutnya dilakukan pembuatan sabun mandi padat dengan beberapa formulasi yang akan diuji kualitas mutu sabunnya. Uji fitokimia untuk antosianin juga dilakukan secara kualitatif, karena antosianin merupakan zat warna yang berperan untuk memberikan warna merah, yang berpotensi untuk digunakan sebagai zat pewarna alami untuk pangan dan dapat juga dijadikan sebagai alternatif pengganti warna sintetis yang lebih aman bagi keehatan (Citramukti, 2008).

\subsection{Pemilihan Pelarut pada Proses Ekstraksi Kulit Buah Naga Merah}

Pemilihan pelarut yang tepat selama proses maserasi itu sangat penting, karena pelarut selama proses maserasi berfungsi untuk menembus membran sel tanaman yang kemudian melarutkan pigmen target sehingga dapat keluar dari sel. Oleh karena itu, pada penelitian ini dibandingkan maserasi antara asam sitrat dengan aquadest. Berdasarkan tabel 1 ternyata kadar vitamin C tertinggi jika menggunakan pelarut aquadest. Sehingga untuk perlakuan selanjutnya pelarut yang digunakan adalah aquadest.

Tabel 1 Kadar Vitamin C Pelarut Aquadest dan Asam Sitrat

\begin{tabular}{|c|c|}
\hline Jenis pelarut & $\%$ kadar Vit C \\
\hline Aquadest & 0,0092 \\
\hline Asam sitrat & 0,0080 \\
\hline
\end{tabular}

3.2 Optimasi Volume Aquadest pada Proses Ekstraksi Kulit Buah Naga Merah

Volume pelarut mempengaruhi proses penarikan pigmen target sehingga dapat keluar dari sel tanaman. Berdasarkan gambar 1 diperoleh hasil yang palingg bagus dengan ditunjukkan oleh kadar vitamin C (kadar antioksidan) yang tinggi adalah saat menggunakan volume aquadest $30 \mathrm{~mL}$. Sehingga untuk penelitian selanjutnya volume aquadest yang digunakan untuk proses maserasi kulit buah naga merah adalah $30 \mathrm{~mL}$.

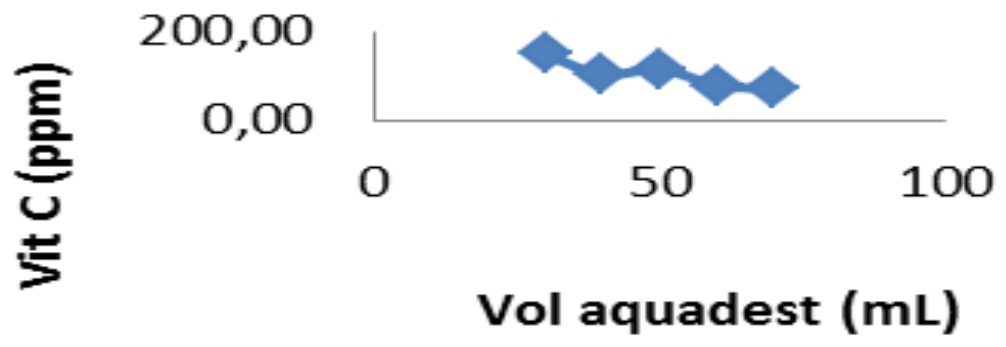

Gambar 1 Kurva Pengaruh Volume Aquadest

\subsection{Optimasi Waktu Maserasi pada Proses Ekstraksi Kulit Buah Naga Merah}

Waktu sangat berpengaruh terhadap kestabilan warna ekstrak kullit buah naga merah. Semakin lama waktu ekstraksi maka dapat menyebabkan terdegradasinya senyawa target, sehingga mengakibatkan menurunnya kadar vitamin $\mathrm{C}$. Penelitian ini menggunakan beberapa variasi waktu maserasi yaitu 1, 2, 3, 4 dan 5 jam. 


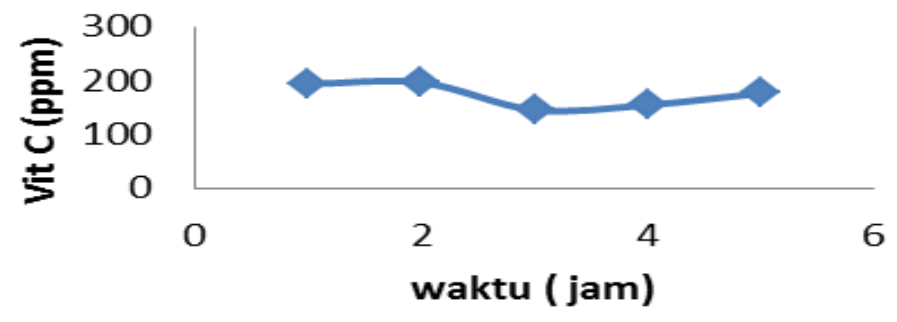

Gambar 2 Kurva Pengaruh Waktu Maserasi

Berdasarkan gambar 2 diperoleh data bahwa variasi waktu maserasi menghasilkan kadar vitamin C yang paling besar adalah 2 jam yaitu 196,20 ppm yang juga menunjukkan tingginya kadar antioksidan dari pada waktu maserasi 1, 3, 4 dan 5 jam. Kadar vitamin $C$ maserasi 1 jam lebih kecil jika dibandingkan yang 2 jam karena kontak antar zat terlarut dengan pelarut semakin lama akan menyebabkan banyaknya zat terlarut yang akan terambil. Tapi saat 3 sampai 5 jam mengalami penurunan jika dibandingkan yang 2 jam, hal ini disebabkan bahwa terlalu lama waktu maserasi akan menyebabkan degradasi, sehingga pada saat pengukuran absorbansi akan menunjukkan kadar vitamin $\mathrm{C}$ yang akan turun juga.

\subsection{Optimasi Suhu Maserasi pada Proses Ekstraksi Kulit Buah Naga Merah}

Kestabilan vitamin $C$ (antioksidan) sangat dipengaruhi oleh suhu saat proses maserasi. Pada penelitian ini suhunya divariasikan dari $10,20,30,40$ dan $50^{\circ} \mathrm{C}$. Hasil penelitian menunjukkan ternyata suhu sangat berpengaruh terhadap ekstraksi kulit buah naga merah dalam menentukan kadar vitamin C (antioksidan).

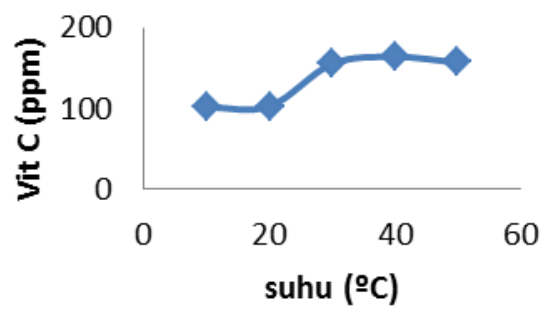

\section{Gambar 3 Kurva Pengaruh Suhu Maserasi}

Dari gambar 3 diperoleh hasil bahwa pada suhu $40^{\circ} \mathrm{C}$ menunjukkan bahwa vitamin $\mathrm{C}$ pada kondisi maserasi ini yang paling tinggi yaitu $163,8 \mathrm{ppm}$. Pemberian suhu tertentu akan mengakibatkan putusnya rantai katan antar molekul pada larutan (Hasanudin, 2001).

3.4 Formulasi Sabun Mandi Padat

3.4.1 Aplikasi Ekstrak Kulit Buah Naga Merah pada Pembuatan Sabun Mandi Padat dengan Berbagai Macam Variasi

Proses pembuatan sabun mandi padat menggunakan metode pemanasan sebagai medianya. Dimana, formulasi dalam pembuatan sabun dilakukan sesuai dengan tabel 2 
Tabel 2 Rekapitulasi Hasil Optimum Uji Kualitas Sabun Mandi Padat

\begin{tabular}{|c|c|c|c|c|c|c|c|c|}
\hline \multirow[b]{2}{*}{ No } & \multirow[b]{2}{*}{ Parameter } & \multicolumn{6}{|c|}{ Perlakuan } & \multirow[b]{2}{*}{ SNI } \\
\hline & & $\begin{array}{c}\text { Formulasi } \\
1\end{array}$ & $\begin{array}{c}\text { Formulasi } \\
2\end{array}$ & $\begin{array}{c}\text { Formulasi } \\
3\end{array}$ & $\begin{array}{c}\text { Formulasi } \\
4\end{array}$ & $\begin{array}{c}\text { Formulasi } \\
5\end{array}$ & $\begin{array}{c}\text { Formulasi } \\
6\end{array}$ & \\
\hline 1 & \begin{tabular}{|l|} 
Sifat kimia \\
Kadar air (\%) \\
Alkali bebas (\%) \\
Nilai pH \\
\end{tabular} & $\begin{array}{c}16,73 \\
0,20 \\
14\end{array}$ & $\begin{array}{c}16,60 \\
0,14 \\
10\end{array}$ & $\begin{array}{c}16,60 \\
0,18 \\
8\end{array}$ & $\begin{array}{c}15,02 \\
0,13 \\
8\end{array}$ & $\begin{array}{c}15,02 \\
0,14 \\
8\end{array}$ & $\begin{array}{c}14,98 \\
0,12 \\
8\end{array}$ & $\begin{array}{c}\text { Maks } 15 \%{ }^{*} \\
\text { Maks } 0,1 \% * \\
9-11 \%\end{array}$ \\
\hline 2 & $\begin{array}{l}\text { Uji Organoleptik } \\
\text { - Proses pemadatan } \\
\text { - Busa }\end{array}$ & $\begin{array}{c}\text { Cepat } \\
\text { Banyak }\end{array}$ & $\begin{array}{l}\text { Cepat } \\
\text { Banyak }\end{array}$ & $\begin{array}{l}\text { Cepat } \\
\text { Banyak }\end{array}$ & $\begin{array}{l}\text { Cepast } \\
\text { Banyak }\end{array}$ & $\begin{array}{l}\text { Cepat } \\
\text { Banyak }\end{array}$ & $\begin{array}{l}\text { Cepat } \\
\text { Banyak }\end{array}$ & \\
\hline
\end{tabular}

Keterangan

$*=$ SNI 3532:2016

$* *$ = ASTM D 1172-95 (2001)

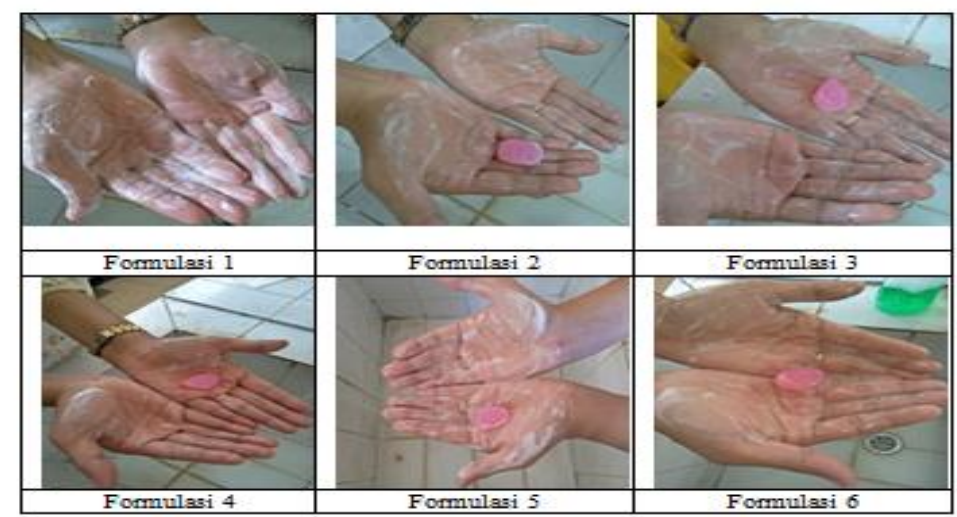

Gambar 4 Hasil Formulasi Sabun Mandi Padat

Berdasarkan tabel 2 dilakukan beberapa optimasi dengan memvariasikan massa minyak kelapa, konsentrasi $\mathrm{NaOH}$, volume $\mathrm{NaOH}$, massa asam stearat, massa gula dan volume ekstrak kulit buah naga merah.

Hasil akhir dari ke enam optimasi tersebut ditunjukkan oleh tabel 2 Pada pembuatan sabun mandi padat, minyak kelapa yang berfungsi sebagai penghasil busa, menghasilkan sabun yang keras serta sebagai agen pembersih pada sabun. Selanjutnya $\mathrm{NaOH}$ akan bereaksi dengan minyak membentuk sabun yang disebut dengan reaksi saponifikasi, sedangkan asam stearat ditambahkan dengan tujuan agar mendapatkan sabun yang tahan lama saat pemakaian. Sebagai pelarutnya digunakan etanol 96\%, untuk melembabkan kulit dimasukkan gliserin pada formulasi pembuatan sabunnya. Sebagai penstabil busa dan surfaktan (senyawa yang aktif menurunkan tegangan permukaan yang bermanfaat untuk menyatukan fasa minyak dan air) digunakan coco-DEA. Sedangkan gula pasir ditambahkan untuk tujuan warna dari sabun tidak terlalu keruh. Terakhir penambahan fragrance oil sebagai pewangi dan ekstrak kulit buah naga sebagai sumber antioksidan yang berfungsi menangkal radikal bebas yang bermanfaat bagi kulit 


\section{KESIMPULAN DAN SARAN}

Dari hasil penelitian dapat disimpukan Hasil pemilihan pelarut yang bagus buat mengekstrak vitamin $\mathrm{C}$ (antioksidan) adalah $30 \mathrm{~mL}$ aquadest dengan waktu maserasi selama 2 jam dengan suhu $40^{\circ} \mathrm{C}$. Proses pembuatan sabun mandi dilakukan dengan metode pemanasan dengan menggunakan penangas air sebagai media pemanasannya. Suhu pemanasan yang digunakan pada saat pembuatan sabun mandi padat adalah 60$70^{\circ} \mathrm{C}$. Untuk penambahan ekstrak kulit buah naga merah suhu diturunkan terlebih dahulu menjadi $50^{\circ} \mathrm{C}$. Dari seluruh perlakuan atau formulasi sabun yang dilakukan penambahan ekstrak terbaik adalah $50 \mu \mathrm{L}, 6$ g minyak kelapa, 12,5 mL NaOH 15\%, 3 g asam stearat, $10 \mathrm{~mL}$ etanol 96\%, 6,5 g gliserin, 7,5 g gula pasir, $500 \mu \mathrm{L}$ coco-DEA, $0,1 \mathrm{~g} \mathrm{NaCl}$ dan fragrance oil $45 \mu \mathrm{L}$

\section{REFERENSI}

- Asterina, Elmatris, dan Eldrinaldi. 2008. Identifikasi dan Penentuan Kadar Boraks pada Mie Basah yang Beredar di Beberapa Pasar di Kota Padang. Majalah Kedokteran Andalan. No. 2, Vol. 32.

- Citramukti, I. 2008. Ekstraksi dan uji kualitas pigmen antosianin pada kulit buah naga merah (Hylocereus costaricensis.). Skripsi.Jurusan Teknologi Hasil Pertanian, Fakultas Pertanian, Universitas Muhammadiyah Malang. Malang.

- Departemen Kesehatan RI, Peraturan Menteri Kesehatan RI No.722/MenKes/Per/IX/1988, tenntang Bahan Tambahan Makanan, Departemen Kesehatan RI, Jakarta, 1989.

- Harborne, J.B. 1987. Metode Fitokimia (diterjemahkan dari : Phytochemical

- Methods, penerjemah: K. Padmawinata dan I Soediro). Penerbit ITB. Bandung.

- Markakis, Pericles. 1982. Anthocyanins as Food Colors 1st Edition. Academic Press

- Nassim et al. 2012. Caracterication and Quantification of Dragon Fruit (Hylocereus polyrhzus) Betacyanin Pigments Extracted by Two Procedures. Pertanika J.Trop.Agric 35(1): 33-40. 20

- Li, C.W., et al. 2006. Antioxidant and antiproliferative activities of red pitaya. 
Journal Food Chemistry. Vol 95: 319-327.

- Rita, Fithri et al, 2015. Ekstraksi Antosianin Limbah Kulit Manggis Metode Microwave Assisted Extraction (Lama Ekstraksi Dan Rasio Bahan : Pelarut). Jurnal Pangan dan Agroindustri Vol. 3 No 2

- Windha I, Wahyunanto, Rini et al, 2015. Ekstraksi Pigmen Antosianin Dari Kulit Buah Naga Merah (Hylocereus costaricensis) Sebagai Pewarna Alami Makanan Dengan Menggunakan Microwave (Kajian Waktu Pemanasan Dengan Microwave Dan Penambahan Rasio Pelarut Aquades Dan Asam Sitrat). Jurnal Bioproses Komoditas Tropis Vol. 3 No. 3,

- Woodward,G, et al. 2009. "Anthocyanin stability and recovery: implications for the analysis of clinical and experimental samples".J. Agric. FoodChem.57 (12): $5271-8$. 